Submitted $20^{\text {th }}$ Juni 2021

Accepted $10^{\text {th }}$ Agustus 2021

\title{
PELATIHAN COOKING CLASS SEBAGAI OBJEK WISATA MINAT KHUSUS DI DESA JEHEM, KABUPATEN BANGLI
}

\author{
A.A.Ayu Suwi Arianty, Komang Trisna Pratiwi Arcana, Komang Ratih Tunjungsari, I Made \\ Trisna Semara \\ Institut Pariwisata dan Bisnis Internasional \\ trisna.semara@stpbi.ac.id
}

\begin{abstract}
Selain objek wisata alam yang dimiliki, Desa Jehem juga memiliki keunikan hayati khas desa tersebut yaitu biu batu. Biu batu merupakan salah satu jenis pisang yang memiliki banyak biji di daging buahnya. Pengembangan wisata minat khusus di Desa Jehem perlu dianalisis mengenai keberlanjutan dari kegiatan wisata tersebut. Tujuan penulisan ini untuk dapat mengetahui kelemahan, kekuatan, peluang, dan tantangan bagi pengembangan Desa Jehem. Manfaat dari tulisan ini diharapkan agar dapat mengetahui strategi pengembangannya dalam persaingan industri pawisisata di Bali. Dalam penelitian ini menggunakan data kualitatif dan kuantitatif. Pengumpulan data pada penelitian ini menggunakan metode observasi dan dokumentasi. Melalui analisis SWOT yang sudah dibahas sebelumnya, maka dapat disimpulkan bahwa membuat manajemen promosi di social media khususnya pembuatan website yang lebih informative.
\end{abstract}

Kata kunci: pengabdian, rangkaian bunga, janur, Korean bouquet wrapping

\section{PENDAHULUAN}

Bali termasuk pulau yang sudah terkenal akan potensi pariwisatanya di mancanegara. Hal ini dibuktikan dari jumlah wisatawan asing ke Bali sebanyak 6.070.473 pada tahun 2018, dimana angka ini munjukkan bahwa $38,40 \%$ wisatawan asing yang datang ke Indonesia mengunjungi Bali (BPS Provinsi Bali, 2019). Objek wisata yang tersebar di setiap kabupaten di Bali baik itu wisata alam, wisata buatan, dan juga desa wisata yang masing-masing memiliki daya tarik tersendiri bagi wisatawan.

Wisata minat khusus telah menjadi trend pariwisata saat ini. Pemerintah telah berupaya untuk mempromosikan seputar kegiatan wisata minat khusus untuk menarik minat wisatawan khususnya wisatawan mancanegara, salah satu promosi yang dilakukan dalam setiap kesempatan, khususnya yang berskala internasional termasuk pada Internationale Tourism Borse di Berlin (ITB Berlin) (KEMENPAR RI, 2012). Salah satu jenis wisata minat khusus adalah desa wisata, dimana desa wisata sudah mulai berkembang di Bali. Pengembangan desa wisata tidak serta merta dapat terlaksana dengan segera, karena banyak hal yang harus dipersiapkan. Desa wisata yang sudah 
cukup terkenal adalah Desa Penglipuran, Desa Wisata Ubud, Desa Wisata Celuk, dan sebagainya.

Salah satu kabupaten yang terletak di Provinsi Bali adalah Kabupaten Bangli. Kabupaten Bangli terkenal dengan objek wisata alamnya, namun yang sudah terkenal hanya beberapa saja seperti Danau Batur dan perkebunan jeruk yang banyak tersebar di wilayah Bangli. Berbicara tentang wisata alam yang dimiliki Kabupaten Bangli sebenarnya masih banyak objek wisata yang tidak kalah indah dengan Danau Batur, salah satunya yang terletak di Desa Jehem, Kecamatan Tembuku. Desa ini memiliki objek wisata Anjungan Desa Jehem atau yang lebih dikeal Anjungan Tukad Melangit (ATM) dimana para wisatawan dapat menyaksikan pemandangan atas tebing yang memukau. Desa ini memiliki iklim sejuk karena terletak di daerah pegunungan.

Selain objek wisata alam yang dimiliki, Desa Jehem juga memiliki keunikan hayati khas desa tersebut yaitu biu batu. Biu batu merupakan salah satu jenis pisang yang memiliki banyak biji di daging buahnya. Walaupun sudah matang pisang ini tidak bisa di konsumsi langsung karena rasanya yang sepat. Biasanya masyarakat mengolahnya terlebih dahulu sebelum di konsumsi, makanan yang dapat dibuat dari biu batu adalah lawar biu batu dan rujak biu batu. Selain bitu batu terdapat juga jeruk keprok khas Desa Jehem yang rasanya manis dan segar, dan sayur jelengot untuk dibuat urap. Melihat keunikan ini, Desa Jehem membuat sebuah cooking class yang memanfaatkan bahanbahan yang menjadi khas desa ini. Cooking class merupakan salah satu wisata minat khusus yang dapat memberikan pengalaman yang lebih bagi para wisatawan dibandingkan hanya berkunjung biasa. Salah satu tempat wisata yang mengembangkan cooking class adalah Rumah Desa yang terletak di Kabupaten Tabanan, Bali.

Menurut Kusudianto dalam Pitana (2009), Penggolongan destinasi adalah sebagai berikut:

1. Destinasi sumber daya alam seperti iklim, pantai, hutan.

2. Destinasi sumber daya budaya seperti tempat bersejarah, museum, teater, dan masyarakat lokal.

3. Fasilitas rekreasi seperti taman hiburan.

4. Event seperti Pesta Kesenian Bali, Pesta Danau Toba, pasar malam dan sebagainya.

Daerah tujuan pariwisata yang selanjutnya disebut destinasi pariwisata adalah kawasan geografid yang berada dalam satu atau lebih wilayan administratif yang di dalamnya terdapat daya tarik wisata, fasilitas umu, fasilitas pariwisata, aksesibilitas serta masyrakat yang terkait dan saling melengkapi terwujudnya kepariwisataan (MENPAR RI, 2018).

Wisata minat khusus sangat dipengaruhi oleh motivasi wisatawan yang akan melakukan perjalanan wisata ke daerah tujuan wisata (Sugiatri, 2013). Ada beberapa kriteria menurut Fandeli dalam Sudana (2013), yang dapat dipergunakan sebagai pedoman dalam menetapkan suatu bentuk wisata minat khusus yakni :

1. Learning, pariwisata yang mendasar pada unsur belajar.

2. Rewarding, pariwisata yang memasukkan unsur pemberian penghargaan.

3. Enriching, pariwisata yang memasukkan peluang terjadinya pengkayaan pengetahuan antara wisatawan dengan masyarakat.

4. Adventuring, pariwisata yang dirancang dan dikemas sehinggan terbentuk wisata petualangan. 
Menurut KEMENPAR RI (2012), wisata minat khusus merupakan salah satu jenis kegiatan wisata yang diminati oleh wisatawan. Wisata minat khusus memiliki prospek yang sangat bagus. Situasi pariwisata saat ini sedang mendukung ke arah itu karena banyak wisatawan yang sudah jenuh dengan objek atau daya tarik wisata umum, seperti taman bertema dan museum, jadi pasar wisata minat khusus ini ada dan akan terus berkembang (Sugiarti, 2013). Daya tarik wisata yang unggul dan berkualitas merupakan faktor kunci yang menentukan motivasi wisatawan untuk berwisata, serta sebagai alasan fundamental yang menjadi pertimbangan megapa seseorang memilih satu destinasi (Ritchie and Crouch, 2003).

Selain itu, paket wisata juga tidak ada di atraksi tersebut, karena wisatawan yang datang ke Desa Jehem sifatnya hanya datang saja, belum ada paket wisata serta belum ada promosi yang memadai dari paket wisata ini. Dilihat dari social media juga tidak ada akun khusus yang mengelola atraksi wisata di Desa Jehem. Akan tetapi penggunaan hashtag memang terlihat digunakan, namun sepertinya belum optimal penggunaannya.

Terkait dengan permasalahan tidak adanya program yang bisa dilaksanakan oleh wisatawan untuk mendapatkan pengalaman, maka dapat diajukan ajaran program cooking class tersebut agar lebih atraktif serta dapat memanfaatkan hasil bumi yang khas yang ada di Desa Jehem dan saat ini malah agak sulit dicari di Kota Denpasar. Cooking clas yang dibuat adalah berdasarkan bahan Biyu Batu (atau pisang Batu, yang memiliki karakteristik khas yaitu memiliki banyak biji ditengahnya). Adapun menu yang ditawarkan juga memang memanfaatkan bahan-bahan yang ada di Desa Jehem, seperti jeruk keprok khas Desa Jehem yang rasanya manis dan segar, digunakan untuk membuat saus pancake. Selain itu, menu-menu khas Bali yang dibuat memang dibuat berdasarkan bahan-bahan yang ada di Green Valley, sehingga ada pengalaman wisatawan nantinya untuk mengambil bahan-bahan segar yang ada di sekitar Desa Jehem. Seperti sayur urap dari sayur Jelengot (yaitu sayur yang tumbuhnya agak liar, dan dapat dimasak dengan metode di blanche). Kemudian setelah program cooking class tersebut terlaksana, maka sebaiknya dibuatkan terlebih dahulu akun dari social media di desa wisata Jehem, agar dapat dipasarkan atau nanti ke depannya dapat bekerjasama dengan agen travel-travel local untuk dapat dipasarkan secara luas.

\section{IDENTIFIKASI MASALAH}

Program pemerintah provinsi Bali dalam rangka meningkatkan pariwisata tapi dapat dinikmati oleh semua kalangan adalah pembangunan desa wisata. Beberapa percontohan untuk pengembangan wisata minat khusus juga dikumandangkan oleh pemerintah provinsi Bali pada saat kepemimpinan Made Mangku Pastika yang ingin mengorbitkan 100 desa wisata pada tahun 2017 yang lalu (Asdhiana, 2017). Sesuai dengan pasal 3 dalam kode etik kepariwisataan yang menyebutkan bahwa kepariwisataan sebagai faktor pembangunan berkelanjutan, maka hendaknya setiap pengadaan kepariwisataan didasarkan dengan konsep tersebut.

Inayatullah (dalam Darmawi, 2010) medefinisikan pengembangan pariwisata berbasis masyarakat atau Community based Tourism Development (CBT), sebagai pengembangan pariwisata yang kekuatannya pada masyarakat dan berwawasan lingkungan yang alami serta menjunjung tinggi nilai budaya tradisional.

Darmawi (2010) juga menjelaskan definisi CBT sebagai pengembangan pariwisata yang mendukung bentuk kepariwisataan dengan menggunakan sumber daya 
lingkungan secara optimal baik sumber daya alam maupun masyarakatnya, menghormati keaslian sosial budaya setempat, memberikan manfaat ekonomi untuk jangka panjang, dan menyediakan pengalaman yang berkualitas tinggi kepada wisatawan serta mempertahankan kepuasan.

Menurut Garrod (2001:4), dalam konsep CBT digunakan dua pendekatan dalam konteks pariwisata tersebut. Pendekatan pertama cenderung mengaitkan keuntungan potensial yang didapatkan dari system perencanaan formal dari ekowisata. Sedangkan pendekatan yang kedua cenderung mengaitkan istilah partisipatif yang lebih memperhatikan keseimbangan antara perencanaan dengan pembangunan serta dampaknya terhadap lingkungan.

Seperti yang diketahui, desa wisata sudah mulai dikembangan di Bali, akan tetapi terdapat suatu permasalahan yang sebagian besar dihadapi oleh para pengelola desa wisata yang ada. Permasalahan tersebut beragam bentuknya, bisa saja permasalahan internal di desa (dikarenakan kecurigaan terhadap investor misalnya), ataupun permasalahan yang memang belum kuat pengkajian pelaksanaan desa wisata. Pengembangan desa wisata tidak serta merta dapat terlaksana dengan segera, karena banyak hal yang harus dipersiapkan. Tempat atraksi saja tidak cukup, harus ada kegiatan lain yang dapat ditawarkan oleh penggiat desa wisata. Setelah atraksi, perlunya media promosi layaknya atraksi wisata lain yang sudah ada. Apabila mencari di mesin pencari elektronik, maka nama desa wisata yang muncul sepertinya desa yang sudah terkenal dan itu-itu saja di Bali, seperti contoh Desa Penglipuran, Desa Wisata Ubud, Desa Wisata Celuk, Desa Wisata Batubulan, dan sebagainya.

Oleh karena itu, perlu diperkenalkan kepada masyarakat untuk dapat mengelola promosi dari desa wisata tersebut. Hal tersebut juga sejalan dengan misi Kementerian Luar Negeri dalam memberikan beasiswa kepada beberapa mahasiswa asing dari berbagai Negara untuk belajar budaya di tiga sanggar seni yang berbeda di seluruh Indonesia. Bali, salah satunya adalah sanggar Semarandana, yang meurpakan sebagai tempat untuk mempelajari budaya Bali bagi mahasiswa asing tersebut. Program Kementerian Luar Negeri ini disebut sebagai Beasiswa Seni dan Budaya Indonesia. Agar program ini dapat berjalan sesuai dengan misi pengenalan budaya dan sebagai diplomasi soft power Indonesia, maka sebaiknya dapat digunakan juga sebagai media promosi bagi Bali secara umum, serta bagi Desa Jehem secara khusus. Khususnya memperkenalkan beberapa daerah yang terkait dengan desa wisata di Bali, agar program desa wisata selain desa wisata yang sudah ada, dapat diperkenalkan di seluruh dunia. Sehingga masyarakat di desa wisata tersebut juga dapat merasakan manfaat dari adanya pencanangan desa wisata tersebut. Desa wisata yang dijadikan mitra adalah Desa Wisata di Bangli, yakni Desa Jehem, yang sudah memiliki atraksi wisata di Anjungan Tukad Melangit (ATM) dan Green Valley, tetapi belum adanya pengelolaan dari segi atraksi wisata yang baik dan juga promosi yang baik.

Selain itu, paket wisata juga tidak ada di atraksi tersebut, karena wisatawan yang datang ke Desa Jehem sifatnya hanya datang saja, belum ada paket wisata serta belum ada promosi yang memadai dari paket wisata ini. Dilihat dari social media juga tidak ada akun khusus yang mengelola atraksi wisata di Desa Jehem. Akan tetapi penggunaan hashtag memang terlihat digunakan, namun sepertinya belum optimal penggunaannya.

Permasalahan dari destinasi wisata di Desa Jehem ini adalah, kurangnya atraksi wisata serta promosi kegiatan yang dapat dihadirkan untuk memberikan suatu nilai tambah pengalaman bagi wisatawan yang berkunjung kesana. Sehingga perlu untuk 
dapat memberikan kesempatan bagi masyarakat desa ikut terlibat membuat suatu paket wisata cooking class yang berdasarkan atas pengalaman bagi wisatawannya.

\section{METODE}

Metode pendekatan yang digunakan adalah lebih ke praktek langsung agar dapat lebih dimengerti dan mengkombinasikan sedikit teori untuk daoat memperkenalkan bagaimana pelaksanaan cooking class. Sehingga pelatihan memasak, dilakukan metode praktek langsung, dengan memberikan kesempatan mahasiswa asing sebagai wisatawan dalam program tersebut. Kemudian pendampingan promosi akan dilakukan secara berkala, dan juga praktek secara langsung. Sedangkan pelatihan Bahasa dilakukan secara teori dan praktek bersamaan dengan sebagian besar langsung praktik. Ceramah juga dilakukan untuk dapat memberikan pemahaman mengenai Bahasa asing serta pemahaman mengenai penggunaan social media. Mitra akan mendapatkan praktek langsung memasak, mencari bahan-bahan yang digunakan, pembuatan social media secara langsung, serta berbahasa asing langsung dengan wisatawan asing. Mitra dapat berbahasa langsung pada waktu praktek serta dapat langsung membuat akun social media tersebut.

\section{HASIL DAN PEMBAHASAN}

Program pemerintah provinsi Bali dalam rangka meningkatkan pariwisata tapi dapat dinikmati oleh semua kalangan adalah pembangunan desa wisata. Beberapa percontohan untuk pengembangan wisata minat khusus juga dikumandangkan oleh pemerintah provinsi Bali pada saat kepemimpinan Made Mangku Pastika yang ingin mengorbitkan 100 desa wisata pada tahun 2017 yang lalu (Asdhiana, 2017). Sesuai dengan pasal 3 dalam kode etik kepariwisataan yang menyebutkan bahwa kepariwisataan sebagai faktor pembangunan berkelanjutan, maka hendaknya setiap pengadaan kepariwisataan didasarkan dengan konsep tersebut.

Inayatullah (dalam Darmawi, 2010) medefinisikan pengembangan pariwisata berbasis masyarakat atau Community based Tourism Development (CBT), sebagai pengembangan pariwisata yang kekuatannya pada masyarakat dan berwawasan lingkungan yang alami serta menjunjung tinggi nilai budaya tradisional.

Darmawi (2010) juga menjelaskan definisi CBT sebagai pengembangan pariwisata yang mendukung bentuk kepariwisataan dengan menggunakan sumber daya lingkungan secara optimal baik sumber daya alam maupun masyarakatnya, menghormati keaslian sosial budaya setempat, memberikan manfaat ekonomi untuk jangka panjang, dan menyediakan pengalaman yang berkualitas tinggi kepada wisatawan serta mempertahankan kepuasan.

Menurut Garrod (2001:4), dalam konsep CBT digunakan dua pendekatan dalam konteks pariwisata tersebut. Pendekatan pertama cenderung mengaitkan keuntungan potensial yang didapatkan dari system perencanaan formal dari ekowisata. Sedangkan pendekatan yang kedua cenderung mengaitkan istilah partisipatif yang lebih memperhatikan keseimbangan antara perencanaan dengan pembangunan serta dampaknya terhadap lingkungan.

Seperti yang diketahui, desa wisata sudah mulai dikembangan di Bali, akan tetapi terdapat suatu permasalahan yang sebagian besar dihadapi oleh para pengelola desa wisata yang ada. Permasalahan tersebut beragam bentuknya, bisa saja permasalahan internal di desa (dikarenakan kecurigaan terhadap investor misalnya), ataupun 
permasalahan yang memang belum kuat pengkajian pelaksanaan desa wisata. Pengembangan desa wisata tidak serta merta dapat terlaksana dengan segera, karena banyak hal yang harus dipersiapkan. Tempat atraksi saja tidak cukup, harus ada kegiatan lain yang dapat ditawarkan oleh penggiat desa wisata. Setelah atraksi, perlunya media promosi layaknya atraksi wisata lain yang sudah ada. Apabila mencari di mesin pencari elektronik, maka nama desa wisata yang muncul sepertinya desa yang sudah terkenal dan itu-itu saja di Bali, seperti contoh Desa Penglipuran, Desa Wisata Ubud, Desa Wisata Celuk, Desa Wisata Batubulan, dan sebagainya.

Oleh karena itu, perlu diperkenalkan kepada masyarakat untuk dapat mengelola promosi dari desa wisata tersebut. Hal tersebut juga sejalan dengan misi Kementerian Luar Negeri dalam memberikan beasiswa kepada beberapa mahasiswa asing dari berbagai Negara untuk belajar budaya di tiga sanggar seni yang berbeda di seluruh Indonesia. Bali, salah satunya adalah sanggar Semarandana, yang meurpakan sebagai tempat untuk mempelajari budaya Bali bagi mahasiswa asing tersebut. Program Kementerian Luar Negeri ini disebut sebagai Beasiswa Seni dan Budaya Indonesia. Agar program ini dapat berjalan sesuai dengan misi pengenalan budaya dan sebagai diplomasi soft power Indonesia, maka sebaiknya dapat digunakan juga sebagai media promosi bagi Bali secara umum, serta bagi Desa Jehem secara khusus. Khususnya memperkenalkan beberapa daerah yang terkait dengan desa wisata di Bali, agar program desa wisata selain desa wisata yang sudah ada, dapat diperkenalkan di seluruh dunia. Sehingga masyarakat di desa wisata tersebut juga dapat merasakan manfaat dari adanya pencanangan desa wisata tersebut. Desa wisata yang dijadikan mitra adalah Desa Wisata di Bangli, yakni Desa Jehem, yang sudah memiliki atraksi wisata di Anjungan Tukad Melangit (ATM) dan Green Valley, tetapi belum adanya pengelolaan dari segi atraksi wisata yang baik dan juga promosi yang baik.

Tabel 1. Jadwal kegiatan pelatihan cooking class

\begin{tabular}{|l|l|l|l|}
\hline NO & \multicolumn{1}{|c|}{ KEGIATAN } & \multicolumn{1}{|c|}{ TANGGAL } & \multicolumn{1}{c|}{ Penanggung Jawab } \\
\hline 1 & Pembukaan & 06 Mei 2019 & I Gst. Ayu Melistyari Dewi \\
\hline 2 & Pengenalan Budaya Asing & 09 Mei 2019 & Komang Ratih Tunjungsari \\
\hline 3 & Pengetahuan Bahasa asing & 16 Mei 2019 & $\begin{array}{l}\text { Komang Trisna Pratiwi } \\
\text { Arcana }\end{array}$ \\
\hline 4 & Pengetahuan menu & 13 Juni 2019 & $\begin{array}{l}\text { Komang Trisna Pratiwi } \\
\text { Arcana }\end{array}$ \\
\hline $\mathbf{5}$ & $\begin{array}{l}\text { Pelatihan Cooking Class: } \\
\text { Balinese Traditional Food }\end{array}$ & 27 Juni 2019 & $\begin{array}{l}\text { A.A.A. Arun Suwi } \\
\text { Arianty }\end{array}$ \\
\hline 6 & $\begin{array}{l}\text { Pemahaman mengenai } \\
\text { promosi online }\end{array}$ & 05 Juli 2019 & Komang Ratih Tunjungsari \\
\hline 7 & $\begin{array}{l}\text { Pembuatan kamus kata-kata } \\
\text { untuk cooking class }\end{array}$ & 12 Juli 2019 & I Gusti Ayu Eka Suwintari \\
\hline
\end{tabular}

\section{DESA JEHEM}

Desa Jehem adalah sebuah desa yang berada di Kecamatan Tembuku, Kabupaten Bangli, Provinsi Bali, Indonesia. Desa ini terkenal sebagai sentra kerajinan sanggah 
Vol 01 No 02, 2021: 72-82

https://dx.doi.org/10.22334/jam.v1i2

(pura keluarga/rumah dalam agama Hindu Bali. Desa ini memiliki luas $9.00 \mathrm{~km}^{2}$, dengan jumlah penduduk 7.354 jiwa. Untuk saat ini belum ada website resmi khusus untuk Desa Jehem, situs website yang dapat dikunjungi adalah https://tembuku.banglikab.go.id, website ini berisi infromasi tentang desa-desa yang ada di Kecamatan Tembuku salah satunya Desa Jehem.

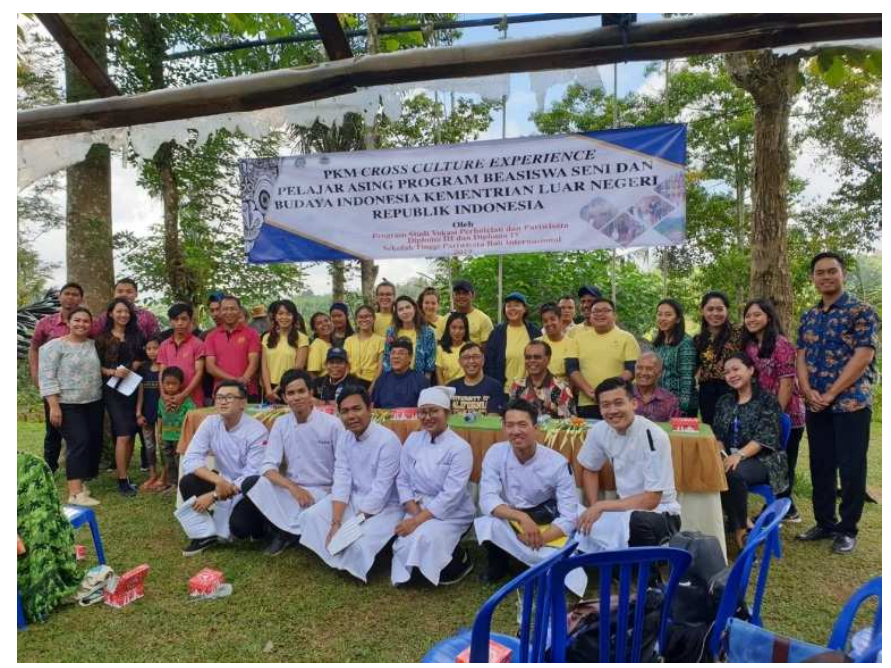

Gambar 1. Foto Bersama Peserta dan Panitia Pengabdian Sebelum Kegiatan

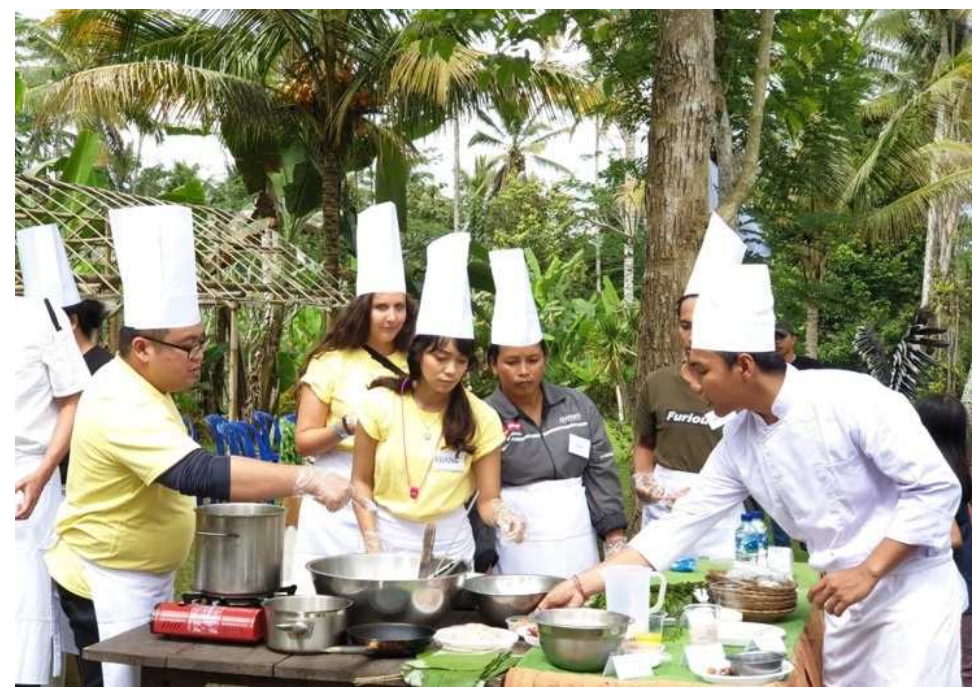

Gambar 2. Foto Selama Kegiatan 


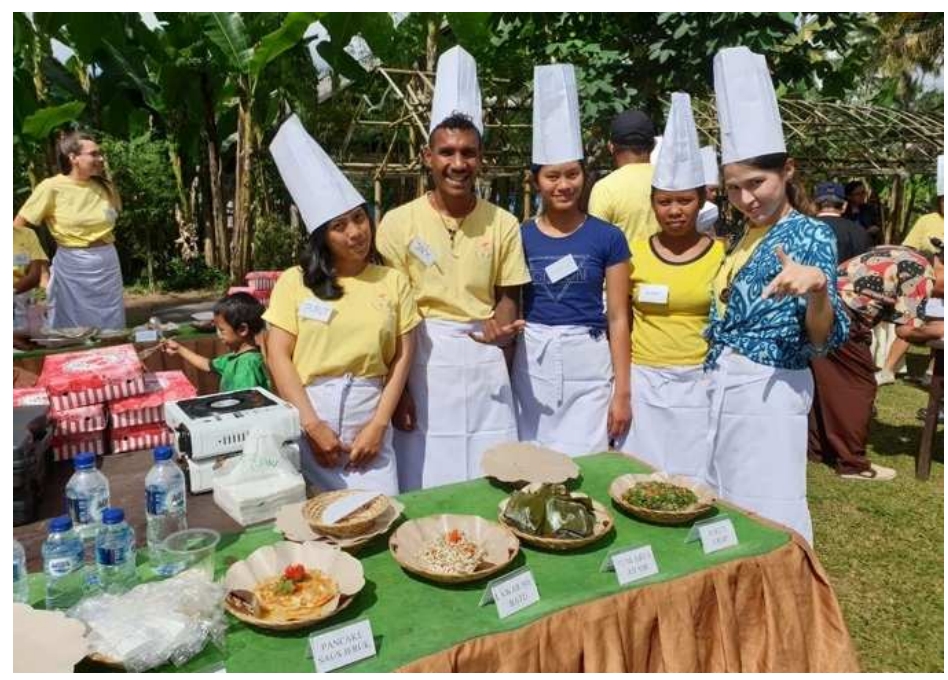

Gambar 3. Foto setelah Menu Masakan Sudah Jadi

\section{Deskripsi Anjungan Desa Jehem / Anjungan Tukad Melangit}

Informasi mengenai objek wisata di Desa Jehem dapat dipublikasikan oleh website pribadi di pencarian internet. Salah satu objek wisata yang sedang berkembang di Desa Jehem adalah Anjungan Desa Jehem atau yang lebih dikenal Anjungan Tukad Melangit (ATM), sebuah anjungan yang menawarkan keindahan lembah yang hijau dan merupakan spot berfoto yang sangat cocok bagi kaum milenial. Objek wisata ATM memang dirancang ideal untuk berfoto. Lokasi ATM ini terletak di dusun Antugan, Desar Jehem, Kec.Tembuku, Kab.Bangli. Berdiri di atas anjungan ini pengunjung dapat melihat keindahan dari lembah hijau Tukad Melangit serta bukit dan pepohonan hijau yang ada di sekitarnya. Anjungan ini dibangun di atas tebing yang cukup curam, dibuat dari bilah-bilah kayu serta batang-batang bambu yang digunakan sebagai dinding pengaman. Anjungan ini hanya dapat menampung maksimal 5 orang karena alasan keselamatan, jadi ketika pengunjung ingin berfoto maka harus rela mengantri apabila sedang kondisi ramai. Bagi pengunjung yang sedang menunggu giliran untuk berfoto di atas anjungan dapat menunggu di posko atau gubuk kecil yang ada disana, selain itu juga bisa bermain ayunan yang tersedia di area objek wisata ini. Gazebo dan tempat duduk untuk bersantai juga disediakan di sini dan terdapat beberapa warung apabila pengunjung ingin membeli makanan dan minuman. ATM ini buka setiap hari pukul 08:00 - 17.00 WITA.

Jarak dari Denpasar menuju Anjungan Tukad Melangit ini sekitar $50 \mathrm{~km}$, dan sekitar $10 \mathrm{~km}$ utara kota Bangli. Untuk fasilitas parkir yang ada apabila membawa mobil pengunjung bisa parkir dekat jalan raya dan berjalan kaki menyusuri jalan setapak sekitar 50 meter, jika membawa sepeda motor pengunjung bisa parkir langsung di lokasi objek wisata tersebut. Harga tiket masuk ke Anjungan Tukad Melangit Rp. 10.000 (dewasa) dan 5.000 (anak-anak). Sedangkan untuk parkir kendaraan gratis. 


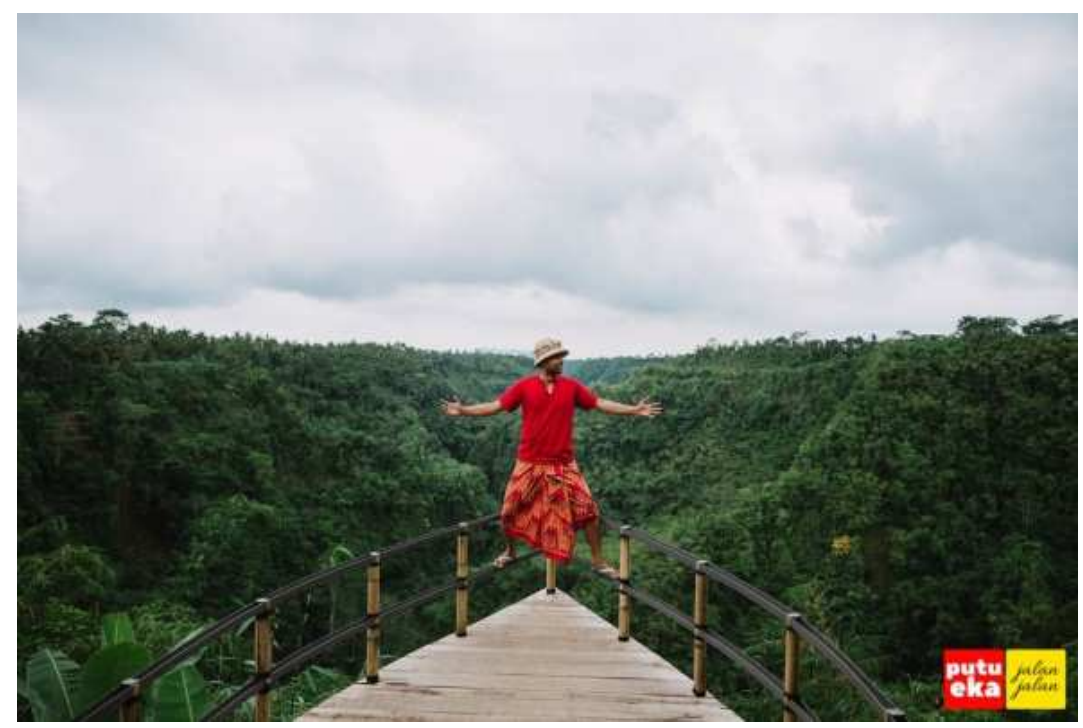

Gambar 2. Anjungan Tukad Melangit

Sumber: Google, 2019

Salah satu social media yang digunakan adalah Tripadvisor dan penilaian di Tripadvisor yaitu 4,5/5. Untuk media sosial instagram Anjungan Tukad Melangit ini belum memiliki akun khusus, hanya ada hastag untuk Anjungan Tukad Melangit ini.

\section{Deskripsi Green Valley Antugan}

Green valley terletak berada tidak jauh dari Anjungan Tukad Melangit. Pengalaman wisata yang bisa didapat di tempat ini tidak jauh berbeda dari Anjungan Tukad Melangit, namun spot foto yang ditawarkan lebih variatif salah satunya adalah anjungan yang dibuat bertingkat. Anjungan selfie bertingkat tersebut dibangun di atas pohon kembar yang lokasinya saling berdampingan. Selain itu juga terdapat spot foto bunga matahari, lorong bunga cantik, dan sebagainya.

Untuk tiket masuk dikenakan biaya 10.000 per orang. Untuk dapat ke lokasi ini membutuhkan waktu kurang lebih 45 menit dari Kota Denpasar, sedangkan dari Kota Bangli berjarak 10km.

Cooking class yang diadakan di Desa Jehem sangat menarik karena para wisatawan dapat mengambil langsung bahan-bahan yang akan digunakan. Selain itu menu-menu yang dimasak merupakan menu special dari Desa Jehem. Untuk harga cooking class ini adalah 350.000 per orang. Untuk media promosi yang digunakan memang belum ada sehingga perlu dibuatkan akun media sosial bagi pengelola agar bisa lebih dikenal wisatawan. Setelah mengambil bahan secara langsung maka wisatawan dapat langsung mempraktekkan proses memasak di dampingi oleh pengelola.

\section{EVALUASI PROGRAM PELATIHAN}

Memberikan beberapa kuesioner untuk masyarakat dapat diisi terkait pelaksanaan kegiatan tersebut. Kuesioner secara online juga diberikan kepada peserta asing, yang merasakan dari kegiatan tersebut seperti apa untuk dapat melihat kelayakan program tersebut. Selain itu, dari dokumentasi juga diketahui bahwa para peserta sangat 
menikmati kegiatan yang telah diberikan untuk pengembangan wisata minat khusus di Desa Wisata Jehem.

\section{DAMPAK PROGRAM PELATIHAN}

Maksud Program ini adalah dapat meningkatkan peranan stakeholder dalam mengembangkan desa wisata Jehem serta pihak Desa Jehem dapat memasarkan produk desa wisata berupa paket wisata, cooking class di Desa Jehem. Setelah pelaksanaan program ini maka manfaat yang didapat bagi Desa adalah manfaat pengabdian masyarakat di Deas Jehem ini adalah meningkatkan pengalaman dan menambah nilai tambah dari suatu destinasi wisata yang ada di Desa Jehem secara umum dan yang ada di Green Valley secara khusus. Mitra akan mendapatkan praktek langsung memasak, mencari bahan-bahan yang digunakan, pembuatan social media secara langsung, serta berbahasa asing langsung dengan wisatawan asing. Mitra dapat berbahasa langsung pada waktu praktek serta dapat langsung membuat akun social media tersebut.

\section{SIMPULAN}

Berdasarkan kajian diatas maka penelitian ini menemukan fakta bahwa secara umum objek wisata Museum Geopark Batur Kintamani ini memiliki potensi yang cukup abgus untuk pengembangan promosi event dalam upaya mempromosikan tempat ini agar lebih menarik banyak pengunjung. Adapun strategi yang dapat digunakan dalam mengembangkan Museum Geopark Batur Kintamani ini adalah dengan memanfaatkan seluruh potensi yang dimiliki mulai dari membuat sebuah event untuk memperkenalkan geopark ini, membuat paket wisata yang mencakup objek-objek wisata lain yang berada di sekitar geopark, dan menangkap pasar potensial terutama kalangan pelajar. Untuk meminimalisir kelemahan maka dapat dilakukan dengan cara pengelola geopark lebih mempelajari pengetahuan dan keterampilan bagaimana memaksimalkan potensi yang dimiliki oleh Museum Geopark Batur Kintamani.

\section{DAFTAR PUSTAKA}

Asdhiana, I Made. 2017. Bali Genjot 100 Desa Wisata Tahun Ini. Lhttps://travel.kompas.com/read/2017/02/21/091700927/bali.genjot.100.desa.wi sata.tahun.ini] Diakses pada 6 Juli 2018.

Badan Pusat Statistik Provinsi Bali. 2019. Jumlah Wisatawan Asing ke Indonesia dan Bali, 1969-2018. www.bali.bps.go.id diakses 05 November 2019.

Baiquni. M. 2004. Manajemen Strategis. Buku Ajar Pusat Studi Kajian Pariwisata Sekolah Pascasarjana Universitas Gajah Mada

Darmawi, Herman. 2010. Manajemen Risiko. Jakarta: Bumi Aksara

Eka. Siskawati. 2018. Exploratory Analysis Vs Explanatory Analysis Dalam Penelitian Kualitatif. www.ekasiskawati.com diakses 07 November 2019

Garrod, Brian. 2001. Local Participation in the planning and Management of Ecotourism: A Revised Model Approach Bristol. England: University of the West England.

Hidayat. Marceilla. 2011. Strategi Perencanaan dan Pengembangan Objek Wisata (Studi Kasus Pantai Pangandaran Kabupaten Ciamis Jawa Barat). Tourism and Hospitality Essentials (THE) Journal. Bandung. 
Jayanti. Dewi. 2011. Analisis SWOT Sebagai Strategi Meningkatkan Daya Saing Pada Hotel Cherry Pink KH.Wahid Hasyim Meda. Skripsi Universitas Sumatera Udara.

Jazuli. Syauqi. 2016. Analisis SWOT Strategi Pemasaran Produk Pembiayaan Pada BMT EL-SYIFA Cianjur. Skripsi Universitas Islam Negeri Syarif Hidayatullah. Jakarta.

Kementrian Pawirisata Republik Indonesia. 2012. Wisata Minat Khusu Memiliki Potensi Untuk Tingkatkan Jumlah Wisatawan. www. Kemenpar.go.id diakses 05 November 2019.

Kotler. Philip dan Gary Armstrong. 2008. Prinsip-Prinsip Pemasaran Jilid 1. Jakarta: Erlangga.

Peraturan Menteri Pariwisata Republik Indonesia. 2018. Petunjuk Operasional Pengelolaa Dana Alokasi Khusus Fisik Bidang Pariwisata. www.dpjk.kemenkeu.go.id diakses 05 November 2019.

Pitana. I. (2009). Pengantar Ilmu Pariwisata. Yogyakarta: Andi.

Pratiwi. Ni Komang Onik. 2017. Analisis SWOT Untuk Meningkatkan Kunjungan Wisata Di Objek Wisata Goa Gajah Desa Bedulu, Kecamatan Blahbatuh, Kabupaten Gianyar Tahun 2017. Jurnal Pendidikan Ekonomi Undiksha. Singaraja

Rangkuti. Freddy. 2006. Analisis SWOT Teknik Membedah Kasus Bisnis. Jakarta: PT.Gramedia Pustaka Utama.

Ritchie. J.R.Brent dan Geoffrey Ian Crouch. 2003. The Competitive Destination: A Sustainable Tourism Perspective.

Sharpley. Richard. 2000. Tourism and Sustainable Development:Exploring the Theoretical Divide. Journal od Sustainable Tourism.

Sudana. I Putu. 2013. Strategi Pengembangan Desa Wisata Ekologis di Desa Belimbing, Kecamatan Pupuan Kabupaten Tabanan.

Sugiarti. Rara. 2013. Pengembangan Kawasan Minapolitan Sebagai Daya Tarik Wisata Minat Khusus di Kabupaten Pacitan. 